Marcin Jurga

http://dx.doi.org/10.18778/8088-635-3.10

\title{
Melancholia, tęsknota i saudade - czyli tożsamość narodowa Portugalczyków
}

Artykut unaocznia kluczowe znaczenie historii w procesie ksztattowania tożsamości narodowej Portugalczyków. Artykuł analizuje m.in. portugalską tożsamość imperialną, mit sebastianizmu oraz fenomen saudade, a także podobieństwa i różnice w postrzeganiu historii w Portugalii i w Polsce.

Stowa kluczowe: Portugalia, melancholia, saudade, naród, tożsamość, historia

Jeśli zapytać przeciętnego Europejczyka, z czym kojarzy mu się Portugalia, to z pewnością najczęstszymi odpowiedziami byłyby osoba Cristiano Ronaldo, upalny klimat, sąsiedztwo geograficzne z Hiszpanią, czy też słynna i ważna dla katolików Fatima. Jednak gdyby przyszło do nieco bardziej szczegółowego określenia cech osobowościowych Portugalczyków, czy też mentalności ich narodu, to najpewniej wiele osób miałoby $\mathrm{z}$ tym problem i raczej podawałoby cechy $\mathrm{Hi}$ szpanów, albo nawet szeroko pojętej społeczności latynoskiej. Jednak trzeba podkreślić, że pod względem kulturowym Portugalczycy znacząco różnią się od często utożsamianych z nimi Włochów, Brazylijczyków, czy nawet tak blisko nich położonych, wspomnianych już Hiszpanów. To mylne często myślenie wynika z niedostatecznej wiedzy dotyczącej mentalności Portugalczyków, która w bardzo silnym stopniu została zdeterminowana unikalną, pełną wzlotów i upadków, przeszłością ich kraju. Ich narodowa tożsamość budowana jest i odwołuje się do wydarzeń nawet sprzed pięciuset lat, bazując na pamięci o prowadzonej przez kilkaset lat polityce kolonialnej, na mesjanistycznym micie sebastiańskim oraz na specyficznym, nieprzetłumaczalnym dla wielu pojęciu saudade. Równocześnie zaś, paradoksalnie, historię i tożsamość Portugalczyków łączy wiele cech wspólnych z narodem polskim. 
Na wstępie warto zaznaczyć, że ludność Portugalii jest dość specyficzna ze względu na to, że pochodzi ona od wielu ludów, które w czasach historycznych osiadały na tychże ziemiach. Znajdowały się wśród nich plemiona celtyckie, germańskie, a także ludy śródziemnomorskie, w tym też północnoafrykańskie. Specyficzne położenie geograficzne Portugalii pozwalało na to, by w jednym czasie przebywali tam przedstawiciele nacji zupełnie się od siebie różniących, co doprowadziło do tego, że doszło tam do dużego rozdrobnienia i zróżnicowania społecznego, które jest odczuwalne nawet do dzisiaj. Warto też wspomnieć o tym, że owe różnice można dostrzec nawet obecnie, przebywając w poszczególnych regionach Portugalii. Im bardziej na północ, tym ludzie znani są z tego, że poważniej podchodzą do życia, skupiając się raczej na sprawach doczesnych, pracy i odpowiedzialności. Z kolei w odniesieniu do mieszkańców południa, żyjących w cieplejszych rejonach kraju, uważa się, że mają zdecydowanie bardziej swobodne podejście do życia, cieszą się nim i są bardziej liberalni w swoich poglądach ${ }^{1}$. Jednak w całym kraju, bez względu na region, można zaobserwować żarliwość, z którą, jak w niewielu innych państwach na naszym kontynencie, celebruje się i powraca do przeszłości.

W Portugalii jest to związane z pojęciem saudade. Termin ten pochodzi od łacińskiego zwrotu solum, który oznacza samotny i odnosi się do swoistej samotności narodu portugalskiego, jaką on realnie odczuwa ${ }^{2}$. W saudade owa samotność przeradza się wręcz w pewnego rodzaju dojmującą melancholię i tęsknotę, przede wszystkim za dawnymi, lepszymi czasami. W przypadku Portugalii jest to tęsknota za latami, w których kraj ten był jednym z najpotężniejszych w Europie, a czas ten przypadał na koniec wieku XV i wiek XVI, kiedy to Portugalia była liderem w odkryciach geograficznych, a podróże Vasco da Gamy czy Bartolomeu Diasa wręcz przyczyniły się do stworzenia nowożytnego świata ${ }^{3}$.

Paradoksalnie, właśnie wówczas w Portugalii zaczęto prezentować postawę o nazwie saudade. Dlaczego? Należy zwrócić uwagę na to, że ówczesne powodzenie Portugalii miało swoją cenę, którą musieli zapłacić zwykli mieszkańcy. Kraj ten był wtedy liderem w odkryciach geograficznych, oraz w pozyskiwaniu zamorskich surowców, stąd koniecznym było, aby jak najwięcej marynarzy udawało się w podróż. Ich wyjazdy powodowały, że zostawiali oni w Portugalii swoje matki, żony i dzieci, często opuszczając bliskich na długie miesiące, a nawet lata ${ }^{4}$. Bywało również tak, że marynarze już nigdy nie wracali do swoich rodzin, gdyż ginęli w czasie podróży, bądź w trakcie pobytu w koloniach.

\footnotetext{
${ }^{1}$ V. Poelzl, Spokojnie, to tylko... Portugalia, Warszawa 2007, s. 12.

${ }^{2}$ Tamże, s. 53.

${ }^{3}$ J. H. Saraiva, Krótka historia Portugalii, Kraków 2000, s. 136.

4 A. Kalinowska-Mitra, Lost in translation - saudade, https://polemizuj.com/article/lost-trans lation-saudade [dostęp: 27.09.2015].
} 
Kobiety zrozpaczone pod stracie mężów, czy synów zakładały żałobne stroje przeżywając stratę swoich najbliższych ${ }^{5}$.

Stałym elementem tożsamości narodowej Portugalczyków saudade stało się jednak dopiero po upadku potęgi tego państwa, który nastąpił w ciągu zaledwie kilkudziesięciu lat od słynnych odkryć geograficznych. Powodem były kryzysy polityczne, militarne i wojskowe, które doprowadziły do ustanowienia w 1580 roku unii personalnej z Hiszpanią, przez jej ówczesnego króla Filipa II. Fakt ten w opinii wielu historyków, w tym José Hermano Saraivy, nigdy nie został wybaczony sąsiadowi i jest powodem wielu niesnasek i konfliktów pomiędzy Hiszpanią a Portugalią, które trwają do dzisiaj ${ }^{6}$. Portugalia już nigdy nie wróciła do dawnej świetności, a dalsze wydarzenia spowodowały tylko pogłębienie kryzysu w państwie. Poczucie saudade pozostało w Portugalczykach do dziś. Państwo do tej pory nie może znaleźć sposobu na przywrócenie dawnej potęgi, a kolejne kryzysy finansowe i polityczne powodują, że frustracja mieszkańców jest coraz większa. Nawet wejście do Unii Europejskiej nie spowodowało wzrostu entuzjazmu w Portugalczykach, gdyż zdaniem wielu z nich wiązało się to $\mathrm{z}$ utratą niezależności narodowej.

Jednym z najbardziej znanych wyrazicieli wspomnianych nastrojów jest portugalski pisarz Gonçalo M. Tavares. W wywiadzie udzielonym Izie Klementowskiej, przytoczonym w książce Samotność Portugalczyka, zauważa on, że o ile Portugalczycy z zasady nie są narodem zadowolonym z życia oraz radosnym, to obecnie można ich określić mianem narodu $\mathrm{w}$ depresji ${ }^{7}$. Tavares podkreśla też, że Portugalczycy to naród ściśle i nierozerwalnie związany $z$ historią i na teraźniejszość zawsze będą oni patrzeć przez pryzmat wydarzeń z przeszłości. Jednak pisarz ostrzega, że takie podejście może być dla Portugalczyków zgubne, gdyż w przeszłości wielu było bohaterów, których dzisiaj wspominają oni z dumą, ale obecne czasy są zupełnie inne i trudno jest zrobić coś naprawdę wyjątkowego, tak jak na przykład Carlos Vegas Gago Coutinho - człowiek, który jako pierwszy w 1922 roku pokonał samolotem trasę Lizbona-Rio de Janeiro, lecąc przez południowy Atlantyk ${ }^{8}$.

Jednym z najbardziej jaskrawych dowodów na wysoki poziom tożsamości narodowej Portugalczyków jest słynny mit o królu Sebastianie, zwany sebastianizmem, który nawiązuje do ideologii mesjańskiej. W Polsce popularność idei mesjańskich przypada głównie na okres zaborów, kiedy idee te zostały spopularyzowane przez polskich wieszczów, na czele z Adamem Mickiewiczem i ko-

\footnotetext{
${ }^{5}$ Tamże.

${ }^{6}$ J. H. Saraiva, Krótka ..., s. 176.

${ }^{7}$ I. Klementowska, Samotność Portugalczyka, Wołowiec 2014, s. 39.

${ }^{8}$ Tamże, s. 44.
} 
jarzą się raczej z biernością i cierpiętnictwem. W Portugalii konotacje z nimi związane są jednak odmienne. Termin ,sebastianizm” pochodzi od imienia króla Sebastiana, który rządził Portugalią pod koniec XVI wieku, u schyłku złotego wieku. Młody władca był od dzieciństwa wychowywany przez duchownych i to spowodowało, że za swój cel obrał misję chrystianizowania innych narodów, co doprowadziło, że w 1578 roku wyruszył na czele krucjaty, której głównym celem było siłowe zaprowadzenie religii chrześcijańskiej w Maroku'. Krucjata zakończyła się jednak klęską Portugalii, a sam król zginął na polu walki, choć jego ciało (przynajmniej oficjalnie) nie zostało nigdy odnalezione.

Okoliczność ta pozwoliła na snucie przez Portugalczyków domysłów, że król jednak przeżył i że pewnego dnia powróci, by wyzwolić swój kraj z niewoli, w jaką wpadł on poprzez unię personalną z Hiszpanią ${ }^{10}$. Wiara ludzi nie ograniczała się tylko do tego, gdyż uważali oni, że król Sebastian wróci, by stworzyć z Portugalii tak zwane Piąte Imperium - na wzór starożytnych imperiów - które będzie w przyszłości rządzić światem ${ }^{11}$. Mit ten przetrwał wiele lat, a jego swoisty renesans nastąpił w XX wieku za pośrednictwem jednego z najsłynniejszych pisarzy tamtego czasu, Fernando Pessoi, który w swoim poemacie Mensagem (Przestanie) przedstawia wizję utworzenia Piątego Imperium i powraca do postaci króla Sebastiana, będącego zbawicielem, niczym Chrystus, a także tym, który odbuduje potęgę swego państwa ${ }^{12}$.

Mit ten pokazuje jak wysokie poczucie własnej wartości jako narodu mają Portugalczycy, bo przecież nie każdy naród potrafiłby określić swój kraj mianem imperium i następcy starożytnych mocarstw, a jednak Portugalczycy nie wahali się głosić takich tez. Mesjanizm ten miał pozytywny wydźwięk o tyle, iż przedstawiał Portugalię w roli aktywnej - jako państwa, które może zmienić porządek na świecie i być potęgą, poprzez pomoc ze strony oczekiwanego Mesjasza (w tym przypadku powracającego króla Sebastiana).

Wysoki poziom tożsamości narodowej Portugalczyków nie został zachwiany nawet w bardzo ciężkich latach w XX wieku, kiedy to państwem rządził Antonio Salazar, którego działania w pewnym stopniu przypominały czyny innych europejskich dyktatorów. To właśnie wówczas do władzy doszła tamtejsza oligarchia, która zajmowała się przede wszystkim swoimi interesami, natomiast zwykli Portugalczycy zostali pozostawieni sami sobie, nierzadko żyjąc w skrajnej biedzie.

\footnotetext{
${ }^{9}$ M. Agnosiewicz, Wojna końca świata, www.racjonalista.pl/pdf.php/s,7134 [dostęp: 27.09.2015].

${ }^{10}$ R. Castleden, Wydarzenia, które zmienity losy świata, Warszawa 2008, s. 220.

${ }^{11}$ V. Poelzl, Spokojnie..., s. 54.

${ }^{12}$ A. Feijó, Fernando Pessoa's Odd Epic, [w:] A Revisionary History of Portuguese Literature, red. M. Tamen, H.C. Buescu, London 1998, s. 146.
} 
By zauważyć, jak rządy w czasach Estado Novo (Nowego Państwa) wpłynęły na życie Portugalczyków, warto odwołać się do wyników badań prowadzonych przez wybitnego holenderskiego socjologa Geerta Hofstede, który zgłębia specyfikę kulturową poszczególnych państw świata, posługując się czterema wyróżnionymi przez siebie wymiarami zaprogramowania kulturowego. Należą do nich dystans władzy, indywidualizm, męskość oraz unikanie niepewności. Wymiar dystansu władzy wskazuje nie tylko na to, jak dane społeczeństwo odnosi się do władzy centralnej w państwie, ale także na przykład na to, jaki stosunek do swych przełożonych mają pracownicy. W społeczeństwach o małym dystansie władzy szef (ani osoby rządzące państwem) nie są traktowani jako nieomylni władcy i pracownicy nie mają oporów przed tym, by wytknąć im błędy, lub by proponować swoje rozwiązania problemów. Wiąże się to też z niewielką hierarchicznością stanowisk, czyli tym, że nie ma aż tak radykalnego rozróżnienia między szczeblami wyższymi a niższymi, co ma tez wpływ na niewielką różnicę w kwestii zarobków. Natomiast odwrotnie jest w społeczeństwach o dużym dystansie władzy. Nie są tam rozwinięte formy protestu społecznego przeciwko władzy (na przykład strajki), a szefa traktuje się z dużo większym respektem $\mathrm{i}$ to on jest osobą decydującą o najważniejszych sprawach $^{13}$. Państwa, w których dystans władzy jest największy, to na przykład Słowacja, Rosja, Rumunia, czy z krajów dalej położonych Filipiny, czy też Meksyk. Natomiast najmniejszy dystans władzy jest w krajach skandynawskich, czyli w Norwegii, Danii czy Szwecji; a także w Austrii ${ }^{14}$.

Indywidualizm to kolejny wskaźnik którym zajmował się w swoich badaniach Geert Hofstede. Jego wymiar wskazuje, czy w danym społeczeństwie interes jednostki jest ważniejszy od dążeń grupy, czy też ma miejsce sytuacja przeciwna. Ludzie państwach kierujących się zasadami indywidualizmu dążą do sukcesu zawodowego, wolą wykonywać pracę samodzielnie niż w zespole, zaś relacje z innymi schodzą dla nich na plan dalszy, ewentualnie ograniczają się do dbania o interes własnej rodziny i przyjació $1^{15}$. Natomiast odwrotnie jest w krajach kolektywistycznych, gdzie ludzie są przyzwyczajeni do życia i interakcji w dużych grupach społecznych i interes grupy staje się dla nich rzeczą nadrzędną, czasami nawet kosztem własnych dążeń. Wpływ na to, czy ludzie myślą w kategoriach wspólnotowych, czy indywidualnych ma wiele czynników, przede wszystkim zaś poziom życia mieszkańców. Zasadą jest, że im bogatsze społeczeństwo, tym większy jest indywidualizm i analogicznie, im biedniejsze

\footnotetext{
${ }^{13}$ G. Hofstede, G.J. Hofstede, M. Minkov, Kultury i organizacje. Zaprogramowanie umystu, thum. M. Durska, Warszawa 2011, s. 69.

${ }^{14}$ Tamże, s. 72.

${ }^{15}$ Tamże, s. 102.
} 
państwo, tym większe zwrócenie się ku grupie ${ }^{16}$. Kolejnym czynnikiem są względy historyczne, a także liczba mieszkańców - jeśli mamy do czynienia z dużym przyrostem naturalnym $\mathrm{w}$ społeczeństwie, to staje się ono niejako z zasady bardziej kolektywistyczne.

Jak z kolei Hofstede definiuje wymiar męskości i kobiecości? Role społeczne, jakie są przyporządkowane kobietom i mężczyznom są właściwie niezmienne od wielu lat i pomimo zmian, jakie mają miejsce na świecie, to jednak wciąż oczekuje się od mężczyzn, że będą cechować się dużą asertywnością, wielbieniem rywalizacji i robieniem kariery zawodowej. Kobiety natomiast mają być uczuciowe, troskliwe i zajmować się domem, dziećmi. Oczywiście jest to w dużej mierze uproszczenie, jednak w badaniach Geerta Hofstede społeczeństwo „męskie” to takie, w którym funkcjonuje jasny podział ról, czyli, jak wcześniej wspomniano - mężczyźni mają być asertywni, twardzi, natomiast kobiety powinny dbać o ognisko domowe. W społeczeństwach „kobiecych” z kolei tak wyraźnych ram nie ma, zarówno od kobiet jak i od mężczyzn oczekuje się właściwie podobnych zachowań ${ }^{17}$.

Natomiast wymiar unikania niepewności wiąże się z określeniem, jakie jest podejście mieszkańców danego państwa do przyszłości i wprowadzania zmian. Im wyższy wskaźnik unikania niepewności, tym dane społeczeństwo bardziej niechętnie odnosi się do sytuacji nowych i niepewnych.

Z badań przeprowadzonych przez Hofstede wynika jasno, że w Portugalii jest niezwykle wysoki poziom unikania niepewności (aż 99 punktów w skali stustopniowej), a także niski poziom indywidualizmu (27 punktów) $)^{18}$. Można założyć, iż na wartość wspomnianych wskaźników znaczący wpływ miała polityka, jaką władze Portugalii prowadziły przez wiele lat w stosunku do swoich obywateli, a która polegała na przykład na ograniczaniu roli kobiet oraz na zmniejszaniu wydatków na edukację, co w konsekwencji prowadziło do utrzymywania się wysokiego analfabetyzmu wśród obywateli, który przez wiele lat był bardzo poważnym problemem.

Podobny wpływ na tożsamość mieszkańców wywarła polityka kolonialna, która odgrywała istotną rolę w kształtowaniu polityki wewnętrznej i zagranicznej Portugalii, aż do lat siedemdziesiątych XX wieku, kiedy ostanie kolonie, takie jak Mozambik, Angola i Timor Wschodni wyzwoliły się spod jej panowania ${ }^{19}$. Wspomniany już wcześniej Gonçalo M. Tavares utrzymuje, że reżim kolonialny, który stosowali Portugalczycy, nie miał tak opresyjnego charakteru, jak chociażby ten, który wiązał się z funkcjonowaniem imperium brytyjskiego, przyznaje

\footnotetext{
${ }^{16}$ Tamże, s. 104.

${ }^{17}$ Tamże, s. 149.

${ }^{18}$ Portugal, http://geert-hofstede.com/portugal.html [dostęp: 29.09.2015].

${ }^{19}$ T. Wituch, Historia Portugalii $w$ XX wieku, Pułtusk 2000, s. 170-171.
} 
jednak, że nieobce mu były akty przemocy, wysiedleń i wszystkie negatywne rzeczy, których odwiecznie dopuszczały się państwa, posiadające kolonie ${ }^{20}$.

Wszystkie wymienione wyżej przykłady pokazują, że historia w bardzo istotny sposób wpływa na tożsamość narodową Portugalczyków. Historia jest tam obecna nie tylko w postaci zabytków i wspomnień, ale jest elementem myślenia, poglądów i wreszcie objawia się w melancholii za dawnymi, minionymi czasami w postaci saudade. Sam naród portugalski jest pełen sprzeczności - z jednej strony chwali się podbojami kolonialnymi i odkryciami geograficznymi, ale $z$ drugiej strony wstydzi negatywnych i nierzadko strasznych wydarzeń, jakie miały wtedy miejsce. Podobnie Portugalczycy uważają się za naród wyjątkowy, a mimo to stoją na uboczu wydarzeń w Europie i obecnie - chociażby ze względu na kryzys finansowy w strefie euro - są raczej obciążeniem dla Unii Europejskiej, do której zresztą mają ambiwalentny stosunek.

Postawa Portugalii może przypominać nieco postawę Polski, gdyż nasze narody łączy naprawdę wiele. Nie tylko burzliwa i obfitująca w wiele zaskakujących wydarzeń historia (za przykład niech posłuży fakt, że w 1926 roku, kiedy doszło do zamachu stanu w Portugalii, podobny zamach stanu miał miejsce w Polsce, za przyczyną przewrotu majowego, dokonanego przez Józefa Piłsudskiego), ale także słynny mesjanizm, chociaż w Polsce jest to bardziej postawa cierpiętnicza, uznająca, że właśnie poprzez cierpienie można wyzwolić państwo i być wyjątkowym narodem. Portugalski mesjanizm był bardziej aktywny, polegał na próbie utworzenia wyjątkowego imperium, z pomocą cudownie ocalałego króla Sebastiana, niemniej jednak w obu przypadkach można mówić o istnieniu silnego mesjanizmu.

Podobnie jest w przypadku zaprowadzania demokratycznych rządów w obu państwach w XX wieku. Zarówno w Portugalii po okresie Estado Novo, jak i w Polsce u schyłku PRL, udało się przeprowadzić zmiany niemal bezkrwawo - w Portugalii w następstwie rewolucji goździków, w Polsce zaś wydarzeń 1980 i 1989 roku.

We wspomnianej już książce Izy Klementowskiej Samotność Portugalczy$k a$ znajduje się niezwykle ciekawy fragment, który zawiera w sobie esencję myślenia Portugalczyków i niech będzie on też podsumowaniem tych rozważań:

Dlaczego my, Portugalczycy, wiecznie za czymś musimy tęsknić? Za światem innym niż Portugalia. Bo kimże my jesteśmy - wejściem do Europy czy jej ujściem? Czy stoimy plecami do Europy, a twarzą do reszty świata, czy odwrotnie ? $^{21}$

\footnotetext{
${ }^{20}$ I. Klementowska, Samotność..., s. 47.

${ }^{21}$ Tamże, s. 14.
} 


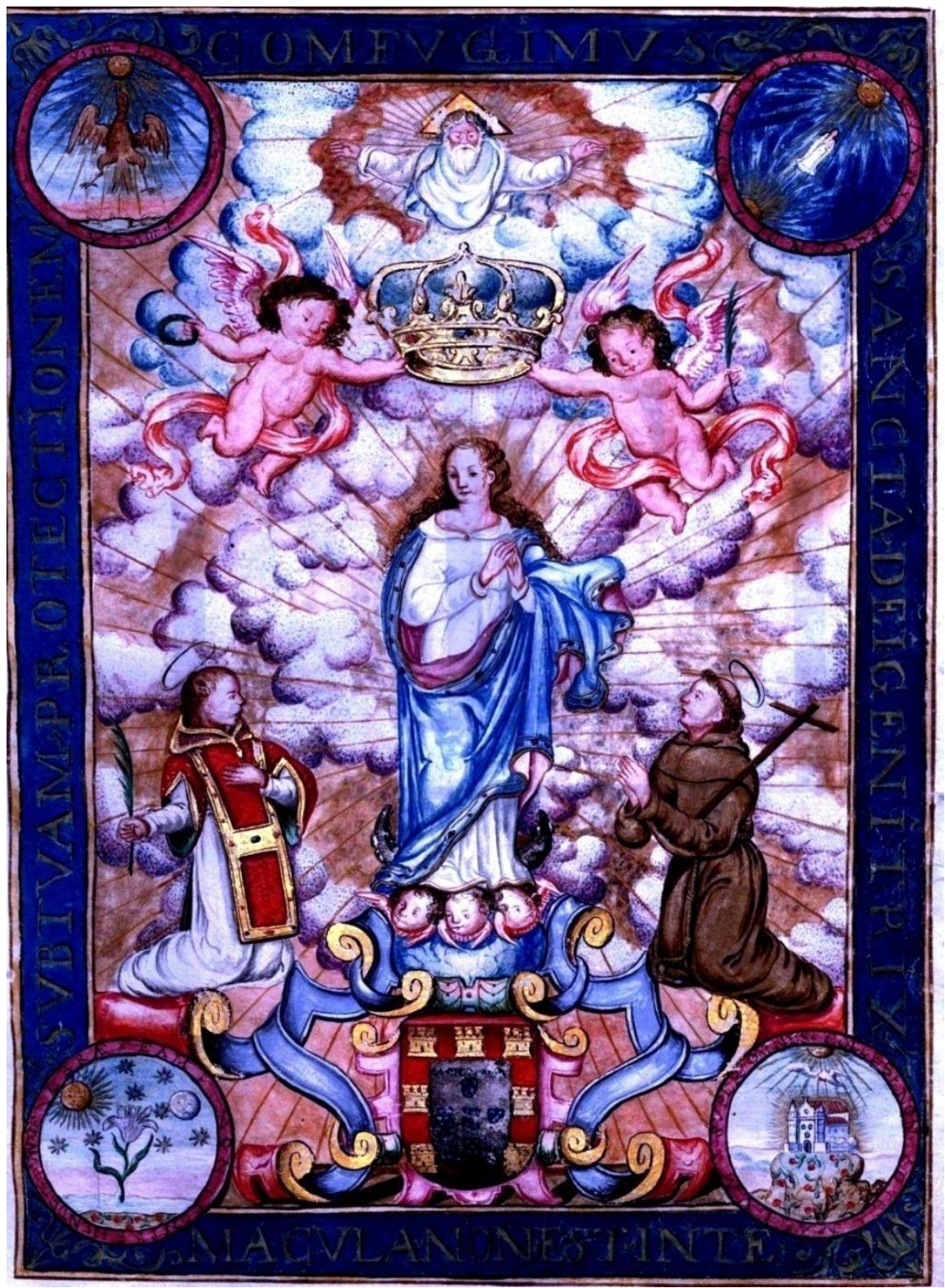

Matka Boża stojąca na herbie Portugalii. Jedna z ilustracji zamieszczonych w herbarzu Thesouro de Nobreza z 1675 r., autorstwa Francisco Coelho ${ }^{22}$.

${ }^{22}$ N.S.a sobre as Armas de Portugal, https://commons.wikimedia.org/wiki/File:Fl-_int-2021_Thesouro_de_Nobreza,_N.S.a_sobre_as_Armas_de_Portugal.jpg [dostęp: 16.08.2016]. 
Thesouro de Nobreza powstało w symbolicznym dla historii Portugalii okresie: w kilka lat po tym, jak Hiszpania uznała jej niepodległość, za panowania Alfonsa VI, zwanego Zwycięskim, drugiego króla Portugalii z dynastii Bragança. Portugalskie imperium kolonialne w Afryce, Nowym Świecie i na Dalekim Wschodzie trzymało się mocno, choć właśnie zostało uszczuplone o Cejlon. Skarb państwa miał wkrótce wzmocnić się za sprawą srebra, odkrytego w Brazylii.

Prawie trzysta lat później, wkrótce po tym, jak premier Portugalii, Antonio Salazar, proklamował powstanie Estado Novo - Nowego Państwa opartego na połączonych ideach korporacyjnych, konserwatywnych i związanych z chrześcijańską nauką Kościoła (obecnie jego koncepcję często określa się jako nawiązującą do idei faszyzmu) - nieznany wówczas nikomu poeta Fernando Pessoa opublikował poetycko-liryczne Mensagem.

W zamieszczonych tam wierszach opiewał on chwałę Portugalii, zawartą w minionych dziejach, opłakiwał jej obecny stan pogrążenia we ,mgle i mroku” i w ciekawy sposób - w tekście Pole zamków - diagnozował szczególną pozycję, jaką Portugalia zajmuje w Europie:

Europa spoczywa podparta łokciami:

Od Wschodu do Zachodu spoczywa i patrzy,

Jej romantyczne włosy spadają na czoło,

Greckich oczu pamięci przysłaniając krasę.

Łokieć lewy - cofnięty;

Prawy - oparty pod kątem.

Tam Italia, gdzie pierwszy;

Drugi to Anglia, odsunięty

By dłoń podeprzeć mogła głowę.

Patrzy spojrzeniem Sfinksa, spojrzeniem fatalnym,

Na Zachód, co przyszłość jej przeszłości wieści.

Patrzy na Zachód twarzą Portugalii ${ }^{23}$.

\footnotetext{
${ }^{23}$ F. Pessoa, Pole zamków, [w:] F. Pessoa, Mensagem = Przestanie, thum. A. da Silva i H. Siewierski, Warszawa 2006, s. 25.
} 


\section{Bibliografia}

Agnosiewicz M., Wojna końca świata, www.racjonalista.pl/pdf.php/s,7134 [dostęp: 29.09.2015].

Castleden R., Wydarzenia, które zmienity losy świata, Bellona, Warszawa 2008.

Hofstede G., Hofstede G.J., Minkov H., Kultury i organizacje. Zaprogramowanie umystu, Polskie Wydawnictwo Ekonomiczne, Warszawa 2011.

Kalinowska-Mitra A., Lost in translation - saudade, https://polemizuj.com/article/lost-trans lation-saudade [dostęp: 27.09.2015].

Klementowska I., Samotność Portugalczyka, Wydawnictwo Czarne, Wołowiec 2014.

N.S.a sobre as Armas de Portugal, https://commons.wikimedia.org/wiki/File:Fl-_int-20-21_ Thesouro_de_Nobreza,_N.S.a_sobre_as_Armas_de_Portugal.jpg [dostęp: 16.08.2016].

Pessoa F., Pole zamków, [w:] F. Pessoa, Mensagem $=$ Przestanie, thum. A. da Silva i H. Siewierski, Warszawa 2006.

Poelzl V., Spokojnie, to tylko... Portugalia, Wydawnictwo Naukowe PWN SA, Warszawa 2007. Portugal, http://geert-hofstede.com/portugal.html [dostęp: 29.09.2015].

Saraiva J. H., Krótka historia Portugalii, Towarzystwo Autorów i Wydawców Prac Naukowych UNIVERSITAS, Kraków 2000.

Tamen M., Buescu H.C., A Revisionary History of Portuguese Literature, Routledge, London 1998.

Wituch T., Historia Portugalii w XX wieku, Wyższa Szkoła Humanistyczna w Pułtusku, Pułtusk 2000.

\section{Melancholy, nostalgia and saudade: on Portuguese national identity}

The article demonstrates the significance of history in the process of creating Portuguese national identity. It analyzes e.g. Portuguese imperial identity, the myth of King Sebastian (Sebastianism), the specificity of saudade, as well as similarities and differences in historical perception in Portugal and Poland.

Keywords: Portugal, melancholy, saudade, nation, identity, history 